Postcolonialism, and International Relations: Reading Race, Gender, Class, pp. 115-141. London: Routledge.

Ling, L.H.M. (2005), "Neoliberal Neocolonialism: Comparing Enron with Asia's 'Crony Capitalism'." In Dirk Wiemann, Agata Stopinska, Anke Bartels and Johannes Angermüller (eds), Discourses of Violence-Violence of Discourses: Critical Interventions, Transgressive Readings and Postnational Negotiations, pp. 93-105. Frankfurt/Main: Peter Lang.

Ling, L.H.M., Hwang, Ching-Chane, and Chen, Bo-yu (2010), “Subaltern Straits: 'Exit', 'Voice', and 'Loyalty' in US-ChinaTaiwan Relations." International Relations of the Asia-Pacific 10(1).

Liu, Xuecheng (1994), The Sino-Indian Border Dispute and Sino-Indian Relations. Landam, Maryland: University Press of America.

Malviya, Gopal (1992), Sino-Indian Relations: Security Environment in the Nineties. Madras: Madras University Press.

Mishra, Binod Kumar (2009), "Articulating an Asian Epistemic Community: Presenting the Other Worldview." Paper presented at an international conference on "Democratizing International Relations," at National Sun Yat-sen University, Kaohsiung, Taiwan, 11-12 March.
Rahman, A. (ed) (2002), History of Science, Philosophy and Culture in Indian Civilization Volume III, Part 2. New Delhi: Oxford University Press.

Rai, Shirin (2003), Gender and the Political Economy of Development: from Nationalism to Globalization. Cambridge, UK: Polity.

Sen, Amartya (2004), "Passage to China." The New York Review of Books 51(19) December 2 [http://www.nybooks.com/articles/ article-preview?article_id=17608]. (Downloaded: 18 February 2008).

Sen, Tansen (2003), Buddhism, Diplomacy, and Trade: The Realignment of Sino-Indian Relations 600-1400. Honolulu: University of Hawaii Press.

Sen, Tansen (2006), "The Formation of Chinese Maritime Networks to Southern Asia, 1200-1450." JESHO 49(4): 421453.

Tan, C. and Geng, Y. (2005), India and China: Twenty Centuries of Civilizational Interaction and Vibrations. New Delhi: Centre for Studies in Civilizations.

Toloken, Steve (2009), "India, China Talk of Expanding Trade Pact: Global Economic Slowdown Spurs Discussions for a Bilateral Strategy." Plastics News 9 February 2009 (http://www. highbeam.com/doc/1G1-193649990.html) (Downloaded: 1 March 2009).

\title{
Political and Socio-Economic Aspects of Gender Equality and the Onset of Civil War
}

\author{
Margit Bussmann*
}

\begin{abstract}
Recent empirical studies showed that societies with less gender discrimination are more peaceful. However, the relationship could be spurious if gender equality captures aspects of good governance, democracy, or the level of development. Empirical results of a sample of 110 countries for the years 1985-2000 indicate that various aspects of gender equality do indeed promote peace even when holding other influences constant. The results of the present study support the notion that improving the situation for women with regard to more political representation but especially more economic participation and better access to health and education improves a society's domestic peace.
\end{abstract}

Keywords: civil war, gender equality, good governance, welfare

Bürgerkrieg, Geschlechtergleichheit, gute Regierungsführung, Wohlfahrt

\section{Introduction}

The literature on civil war frequently concentrates on ethnic and religious polarization or economic inequality as sources of violence. Discrimination against and systematic exclusion of large parts of the population are considered to be main causes of

\footnotetext{
Dr. Margit Bussmann is Professor for International Relations at Ernst Moritz Arndt University, Greifswald. For helpful comments on this article I would like to thank Volker Franke and two anonymous reviewers.
}

ethnically motivated violence. Another form of discrimination in society, gender inequality, is not on the forefront of research on armed conflict. Only few empirical studies investigate and support the peacefulness of societies that experience less gender discrimination (Caprioli 2005, Melander 2005a,b). Explanations for this mostly refer to a general pacifism of women as a result either of nature or socialization. Consequently, so the arguments, women in positions of power are more hesitant in deciding to use military force. The peacefulness of states could be enhanced if the position of women would be strengthened 
not just in politics but also on the societal level. Hence, it is important that an analysis clearly distinguishes between gender equality on the political decision-making level and gender equality in the socio-economic spheres of life.

Whereas there are good reasons to expect that gender equality enhances civil peace, the relationship could be spurious and might show up in statistical analyses because both variables are related to confounding factors that are omitted. A higher participation of women in politics and in the formal labor market and more educational equality increases competition. As a result of the competitive environment, corruption and rent-seeking is inhibited, improving the quality of governance. And, according to recent conflict studies (e.g. Fearon \& Laitin 2003), good governance is an essential component for a peaceful environment. Gender equality is not just related to good governance but also to a state's level of development and democracy. It is thus essential to incorporate these potentially confounding factors in the analyses to ensure the ability to measure gender equality as effect on domestic peace and avoid it serving as proxy for other pacifying influences, such as good governance, democracy and economic development.

In the next section I will summarize the theoretical arguments and previous empirical findings, linking political representation of women and gender equality on the societal level directly to more civil peace. In section three I will lay out possible objections to this relationship between gender equality, namely that the findings are biased due to the omission of controlling for good governance, the level of development, and democracy. The research design used to test the claim is described in part four, followed by the presentation of results and a concluding section.

\section{Gender equality and peace}

Studies on public opinion confirm that women are generally less supportive of the use of military force than men (Nincic $\&$ Nincic 2002; Wilcox et al. 1996). The more pacific attitudes of women on average should eventually translate into policy if we assume that public opinion is an important factor in policymakers' decisions (Powlick 1995). An adequate representation of women in the political decision-making processes could thus be a constraint for the government to use force. In particular, women as head executives or as defense ministers are in positions to decide about the deployment of the armed forces. However, detecting the peacefulness of female state leaders in statistical analyses is somewhat problematic as female chief executives are still quite rare (Caprioli 2003; Melander 2005a,b).

High female representation in parliament can also serve as a constraint because, depending on the political system, decisions on the use of armed forces frequently need to pass through the legislature. Indeed, several empirical studies link gender equality in political representation directly to more peace. For international conflicts, Regan and Paskeviciute (2003) find that two states that have a high percentage of women in parliament are less likely to become involved in a military dispute with each other. Melander (2005a) demonstrates that states with a higher percentage of women in parliament experience lower levels of intrastate conflict. He also shows that states with more gender equality in terms of more political representation, i.e. the percentage of women in parliament, are more inclined to follow human rights (Melander 2005b).

There are mainly two types of explanations for the effect of gender equality on the peacefulness of states and societies offered in the literature. Whereas some rely on biological gender differences, in particular on aggression theories, and the women's reproductive role in explaining female pacifism, a constructivist version emphasizes gender identity and more wide-spread norms about gender equality. Boys and men are socialized to be tough and warlike, whereas girls and women are socialized to empathy and subordination (Caprioli 2003; Melander 2005).

Another explanation stresses that it is in the women's selfinterest to be opposed to the use of military means and violence. If women are the major victims of war, armed conflict is not in their interest as they have more to lose than to gain. Whereas more men than women get killed or harmed directly in combat, ${ }^{1}$ armed conflict is indirectly much more damaging to women. While women have a longer life expectancy in peacetime, the gap between female and male life expectancy narrows as a result of armed conflicts. Indirect consequences of war, such as shortage of food and clean water, damaged (health) infrastructure, displacement of population affects women disproportionately. In male dominated societies women are rather positioned at the end of the distribution chain of food and health care (Plümper \& Neumayer 2006). Women are indeed less likely to support military interventions that are associated with high costs and risks (Nincic \& Nincic 2002). Women are typically poorer than men and thus more reluctant to support actions that increase the military budget at the cost of government spending on social welfare (Wilcox et al. 1996).

More women accessing the labor market could also weaken potential rebel movements. Working women contribute to the household income, which reduces pressure on the male bread winners who, in case regular and legal work is not available, might turn to rebel movements or the military as income source, or differently put, forgone income is low by enlisting in a rebellion (Collier \& Hoeffler 2004). The improved bargaining position of working women makes them more assertive and facilitates the enforcement of their position at home. In most cases, a woman will prefer a working and assisting husband at home to a fighting husband on the battlefield. On the other hand, higher female labor force participation could leave young males unemployed, thus increasing the main source for rebel recruitment. According to Collier and Hoeffler's (2004) study, employment and male secondary school enrollment are inversely related to the outbreak of civil war as these variables reduce the pool of potential rebels.

1 In some conflicts women suffer directly from widespread sexual violence, used either strategically to frighten or punish a certain group or in an opportunistic manner, depending on the absence of respective norms and sanctioning mechanisms (Wood 2006). 
In this context reverse causality needs to be considered: conflict can lead to more female labor force participation, in the aftermath but also in preparation of a war when women have to take over the jobs previously done by men. Reverse causality is also plausible with regard to the relationship between civil war and gender equality in education and life expectancy as an ongoing civil war, but less so the start of a civil war, has negative consequences on the welfare of the general population but especially for women (Plümper \& Neumayer 2006).

Several researchers investigated the direct effect of gender equality on armed conflict. Quantitative-empirical studies found that a high fertility rate and low female labor force participation increase the risk of domestic and international conflict (Caprioli 2003, 2005; Regan \& Paskeviciute 2003) as does a lower ratio of female-to-male school attainment (Melander 2005a). However, the relationship might be spurious and in reality be caused by a third factor.

\section{Gender equality as a proxy for good govern- ance, development, democracy}

Political and economic participation of women could serve as proxies for other factors that influence peace. The level of development, democracy, and good governance are extensively studied in the literature on civil war and also are related to concepts of gender equality. Thus, it is important to take these potentially confounding factors properly into account when studying the effect of female participation in political, economic, and societal life as a source of peace. Otherwise, the relationship between gender equality and civil peace might be spurious. Whereas some studies control for the level of development or the type of political regime (Caprioli 2005, Melander 2005), none holds good governance constant, although it received widespread attention in studies on civil war (Fearon \& Laitin 2003).

Economic development: The positive effect of economic development on peace is one of the few robust statistical findings in the civil war literature (Hegre \& Sambanis 2006). One explanation is rooted in grievance, resentment, and dissatisfaction in the population of poor countries. People dissatisfied with their situation are more likely to go to the streets in protests that might then turn violent, or more likely support rebel movements that claim to fight for a better life. Economic development and indicators of gender equality are also related. Dollar and Gatti (1999) confirm in their empirical study that "good times are good for women" (21), as increasing income per capita is positively related to indicators of gender equality in education and health (see also Brown 2004). Not just education but also female labor force participation varies with the level of development (Tzannatos 1999).

Democracy: Several studies confirm that the risk of civil war is highest in states with inconsistent political regimes, whereas consistent democracies but also autocracies are more peaceful. In democracies, there are peaceful mechanisms for the population to voice discontent and to resolve conflicts; in autocratic systems any emerging opposition can be forcefully suppressed (Hegre et al 2001). Studies also point to a positive effect of female participation and equal educational opportunities for democracy (Barro 1997). Women who are more educated and active in professional life are more likely to vote. In turn, the ruling elite will be more attentive to this public and to its preferences. Furthermore, political systems with an open and competitive recruitment process allow access for more female politicians who in turn will champion more educational opportunities for women and who also serve as a role model to other women (Brown 2004; Thomas 1991).

Good governance: States that are well governed are politically more stable. A weak government is unable to monopolize the use of force allowing insurgency movements to emerge (Fearon \& Laitin 2003). Others emphasize the economic tasks a state needs to fulfill, such as the provision of public goods and the redistribution of income (Azam 2001) and again others point to institutional features and an efficient bureaucracy to ensure transparency and avoid rent-seeking (Weede 1998). Corruption and patronage at a minimum and the rule of law but also the transparency and accountability of institutions are among the main characteristics that are frequently associated with a good quality of governance (Holmberg, Rothstein \& Nasiritousi 2009). ${ }^{2}$ Policies that aim to create an open and competitive environment inhibit corruption and rent-seeking. One way to enhance competition is to enlarge the pool of qualified candidates for positions in the public or private sectors. This can be done by improving the education of girls and women, also compared to men, and encouraging more participation of women in politics and the formal labor market. With a large minority group of women excluded from political and economic life, a state reduces competition for political and economic posts leading to corruption. Empirical studies did, indeed, detect that if women hold a larger share of seats in parliament and in government, and participate more in working life, there are lower levels of corruption in a country (Swamy et al. 2001; Dollar et al. 2001). In the World Values Survey more women than men reject the hypothetical acceptance of bribery (Swamy et al. 2001).

In sum, there are various arguments that relate gender equality to more domestic peace. Both are also associated with democracy, good governance and economic development, variables that could account for a spurious relationship if not properly controlled. The present study will test if gender equality, in terms of more women in parliament, in the labor market, in schools and with better health reduces the likelihood that a civil war will break out in a country in the following year if confounding factors are held constant.

\section{Research design}

The arguments outlined above were tested with logistic regression analysis. A logit model is appropriate because the dependent variable is the onset of a civil war which has either the value one or zero. It predicts the probability that a civil war

2 Good governance is a broad concept that can encompass many different concepts and the debate on a standard definition is still ongoing. For an overview see Holmberg, Rothstein \& Nasiritousi (2009). 
will start in a given year. ${ }^{3}$ The data cover 110 countries over the years 1985 to 2000 . By using multiple regression analysis we can hold various other influences constant, in particular variables that could potentially be confounding factors, such as the level of development, the political regime type and good governance, but also variables that are identified in previous work to be robustly related to the onset of civil war, like the size of the population. The independent variables of main interest are various indicators for gender equality in political representation, professional participation, educational aspects and health aspects to distinguish whether only women's access to political power or also more equality and participation on the societal level are related to peace. The explanatory variables are lagged by one year to encounter potential problems of endogeneity, specifically that the relationship is subject to reverse causation, as there is concern that a civil war might affect the current values of female political and economic participation and welfare. Thus, the explanatory power of the gender variables will be tested for an onset of civil war in the following year. Below I will briefly describe the operational definition of the various variables and their data sources, first for the dependent variable in the conflict model and its control variables and then, in more detail, for the gender variables.

The model of conflict onset: The dependent variable is the onset of domestic armed conflict as defined in the Uppsala/PRIO data set which includes all armed conflicts between the state government and another organized group that concern an incompatibility over government or territory and that have at least 25 battle-related deaths (Gleditsch et al. 2002). The multivariate model of conflict contains the variables for gender equality but also several control variables. As described above, the aim of the study was to test the effect of various variables for gender equality while holding potentially confounding factors constant. Therefore I included the level of development, democracy, and political regime type as control variables. The level of economic development is measured as the logarithmic transformation of real GDP per capita on a purchasing power parity basis in constant 1995 international dollars with data from the Penn World Tables 6.1 (Heston et al. 2002). Democracy and its square term control for the curvilinear relationship with data from Polity IV, which combines various institutional characteristics of a political system to an index ranging from -10 for autocracies to +10 for pure democracies (Marshall \& Jaggers 2000). The composite international country risk guide (ICRG) index as a measure of good governance (Keefer \& Knack 1995) is an overall indicator based on 22 components that rate political, financial, and economic risk, and is available from the World Development Indicators 2004. Ranging from 0 as highest risk to 100 as lowest risk, high values are standing for good governance. ${ }^{4}$ The composite index captures the full spectrum of quality of governance. The individual components

3 The model of conflict onset is estimated with a pooled time-series cross-section logit model with White-corrected robust standard errors.

4 The individual components for political risk are government stability, socioeconomic conditions, investment profile, internal conflict, external conflict, corruption, military in politics, religious and ethnic tensions, law and order, democratic accountability and bureaucracy quality. The financial and economic risk indicators are for example the inflation rate, foreign debt, GDP and the exchange rate stability. More detailed information about the ICRG methodology can be found at http://www.prsgroup.com/ICRG.aspx. that particularly account for good governance (quality of bureaucracy, corruption in government, and the rule of law) are highly correlated among each other but also with the composite index (Olson et al. 2000).

I also included the yearly growth rate of GDP per capita to account for the notion that prosperous countries are less likely to become involved in a domestic conflict. Furthermore, the logarithm of population controls for the heterogeneity of large countries that have presumably an increased risk of civil war. Data is taken from Heston et al. (2002). Other variables frequently used in studies on civil war were not included, such as civil war in the neighborhood or years of peace, as I do not expect them to be intervening variables. This is to keep the model parsimonious.

Women in parliament and years of suffrage: Information on the percentage of parliamentary seats that are held by women in the single or the lower chamber, in case of bicameral assemblies, is available from Melander (2005). Based on information from the Inter-Parliamentary Union on the introduction date of voting rights for women, I calculated a variable accounting for the number of years since women have the voting right. Besides of voting being a form of political participation in itself, presumably political participation on all levels will be more anchored, the longer women have the right to vote.

Female labor force participation: Besides political representation, women's activities in the economic sphere are important as well. With regard to the participation of women in professional life, this study examined the effect of female labor force participation, namely the number of women that are active in the labor force as a percentage of total labor force.

Female life expectancy and education: The female life expectancy at birth reflects health aspects or the physical quality of life (Gray et al. 2006). Female life expectancy in absolute numbers is a measure of general female welfare, ${ }^{5}$ and to assess inequality more directly, the ratio of female to male life expectancy was tested. The operational definition of education used here is the secondary school enrollment rates of females, using the gross ratio (number of children of all ages enrolled in school in relation to the population of the respective age group). As this variable does not undergo strong yearly fluctuations, the observations were inter- and extrapolated to reduce missing values. Again, the absolute level and the ratio between female and male education levels were analyzed. Data on the various education variables, the labor force participation and life expectancy are available from World Development Indicators 2004 .

\section{Results}

The results presented in the table provide us with information about whether indicators for gender equality are related to the

\footnotetext{
5 Studies that assess the effect of female poverty and participation in economic life rely on education and health proxies (e.g. Gray et al. 2006). Analyzing female poverty directly is problematic because income is usually collected female poverty directly is problematic because income is usually collected
on the level of the household without differentiating between the individual members.
} 
onset of civil war, as reported in other studies, when controlling for good governance, democracy and economic development. With regard to the control variables, economic growth has the expected negative coefficient, supporting previous findings that countries with a growing economy are less likely to see the onset of a civil war in a given year. Populous countries are more at risk of experiencing the outbreak of a civil war. Furthermore, the results show that domestic unrest systematically varies with the type of political regimes but not in a linear fashion. Polity and its square term are jointly highly significant and support the inverted U-curve of the relationship indicating that mixed political regimes are most prone to experience domestic violence, whereas democratic states but also autocratic states are less at risk. Economic development, measured as log (GDP per capita), is negatively related to the onset of armed conflict. Civil war is more prevalent in poor countries. Some of this variable's explanatory power is absorbed by other variables. The level of development is highly correlated with several of the other independent variables, in particular with the index for good governance $(r=-.79)$. The indicator of good governance, the ICRG index, is negatively related to the onset of civil war and it is statistically highly significant in most tests. States with good governance are more peaceful. Interestingly, it is the overriding variable which underlines Fearon and Laitin's (2003) approach of using the level of development as a proxy for state capacity. Without its inclusion GDP per capita turns out to be a highly significant conflict-impeding factor supporting the results of others (e.g. Hegre \& Sambanis 2006).

Economic development is also highly correlated with some of the gender variables, in particular with female life expectancy and female secondary school enrollment $(\mathrm{r}=.87)$. Clearly, women in developed countries have a higher life expectancy and better access to education. Thus, multicollinearity in the analyses makes it more difficult to clearly distinguish the impact of the individual predictors. This could lead to an erroneous conclusion that the gender variables might have no impact, if all their explanatory power were to be absorbed by correlated factors. One solution would be to drop the level of development but this increases the risk of omitted variable bias, in which case there might be a danger of overemphasizing the effect of gender equality. Thus, I decided to keep the level of economic development in the model to provide a strenuous test for the gender variables. I report below if the exclusion of GDP per capita alters the results.

Various indicators of gender equality were added one by one to the baseline model of conflict. In column 1 of the table, the share of women in parliament is not significantly related to the onset of conflict, albeit with the expected negative coefficient. The variable remains insignificant if we exclude good governance or the level of development from the equation and just reaches the significance level of .10 if democracy and its square term were dropped. Thus, some of its effect might be absorbed by the type of political regime as democracies tend to have a higher female representation in parliament. Otherwise, the variable is not significant and robust enough to have sufficient confidence that a direct relationship between political representation of women and civil war exists. In column 2 , the length of female suffrage is statistically not significant, not even in a bivariate analysis without any control variables. The results of these first tests do not support the argument that societies were more peaceful with more women in power. Instead, the variables accounting for a higher share of female parliamentarians or for women's suffrage appear to be unrelated to whether a country experiences a civil war.

The next tests presented in the table concentrate on variables that capture gender equality on the societal level. In column 3 , I report the results of a relationship between women's participation in work life with the onset of a civil war. The female labor force participation is significantly related at the .10 level to the onset of civil war with a negative coefficient. The finding implies that an increased participation of women in the formal labor market enhances domestic peace, even when other influences are held constant. The effect is stronger if democracy or good governance is excluded from the model specification. Thus some of the impact of female labor force participation is absorbed by the quality of governance, but the gender variable still has a direct effect on a society's domestic peace. However, the result is conditional on the inclusion of the level of development. Altogether, there is evidence that a higher share of women in the labor force is related to a smaller risk that a conflict will break out in the following year even if confounding factors such as good governance are held constant. Higher female employment is not only related to better quality of governance, as stipulated by the literature, but also seems to be beneficial for civil peace.

Next, I analyzed variables that relate to health and educational aspects of women's welfare and gender equality. Female life expectancy has a highly significant conflict-inhibiting effect even in the presence of potentially confounding factors. The finding in column 4, however, refers to absolute levels of female life expectancy. Female and male life expectancy are highly correlated, thus the variable could serve as an indicator for general welfare. Therefore, it is necessary to also evaluate the life expectancy of women relative to men's, as an indicator of relative gender inequality, if we want to find out if gender discrimination is related to civil war. In column 5 , a higher relative female-to-male life expectancy is also associated with a lower likelihood that a civil war will break out, again even when we control for good governance, democracy and development. The result largely persists when any of these variables are excluded from the analysis. This supports the claim that absolute but also relative welfare for women is positively associated with domestic peace.

A similar picture emerges for female secondary school enrollment which is negatively associated with the onset of armed conflict. This variable, however, is only marginally significant in column 6 . Some of its effect is absorbed by the level of development, two variables that are highly correlated and are thus difficult to disentangle. Female-to-male secondary schooling, as a proxy for gender equality in education, has the expected negative coefficient and is highly significant (with and without good governance, democracy, or development in the equation). Societies with relatively more girls in secondary schools are less likely to experience the onset of civil war. Improving the health situation of women and providing 
better access to education appear to be possible routes to more peace.

\section{Conclusion}

Besides an advocacy of gender equality in its own right, the rewards of a more equal representation and participation of women are manifold. Women playing a more important role in economic and political life is not just advantageous to the female population but to society as a whole. Gender equality can help to reduce poverty, and beyond that, providing women with more equal opportunities can be a force for peace. The results of the empirical analyses of 110 countries for the years 1985-2000 indicate that gender equality is indeed related to more civil peace even when holding a country's level of development, quality of governance, and democracy constant. The present study supports the notion that improving the situation for women with regard to more economic participation and better access to health and education improves a society's prospects for domestic peace. Whereas the number of women in parliament is less clearly a force for peace when confounding factors are held constant, gender equality on the societal level in form of female-to-male life expectancy and schooling but also a higher labor force participation of women reduces the likelihood that a state will experience a civil war.

Table 1: The effect of gender equality on the onset of civil war

\begin{tabular}{|c|c|c|c|c|c|c|c|}
\hline COEFFICIENT & (1) & (2) & (3) & (4) & (5) & (6) & (7) \\
\hline \multirow[t]{2}{*}{ Polity, t-1 } & 0.2360 & $0.2801^{*}$ & $0.2653^{*}$ & $0.2898^{*}$ & $0.3118^{*}$ & $0.2628^{*}$ & $0.3195^{* *}$ \\
\hline & $(0.2263)$ & $(0.1946)$ & $(0.1957)$ & (0.1900) & (0.1909) & (0.1909) & $(0.1933)$ \\
\hline \multirow[t]{2}{*}{ Polity square, t-1 } & -0.0093 & -0.0110 & -0.0108 & $-0.0113^{*}$ & $-0.0126^{*}$ & -0.0103 & $-0.0118^{*}$ \\
\hline & $(0.0098)$ & $(0.0088)$ & $(0.0086)$ & $(0.0084)$ & $(0.0084)$ & $(0.0084)$ & $(0.0084)$ \\
\hline \multirow[t]{2}{*}{$\log (\mathrm{GDP} p \mathrm{p}), \mathrm{t}-1$} & $-0.4452^{*}$ & -0.2830 & $-0.4620^{* *}$ & 0.3109 & -0.0783 & 0.0568 & 0.0754 \\
\hline & $(0.3420)$ & $(0.2902)$ & $(0.2367)$ & $(0.2842)$ & $(0.3055)$ & $(0.3624)$ & $(0.2973)$ \\
\hline \multirow[t]{2}{*}{ Economic growth } & -0.9396 & $-3.2426^{*}$ & $-3.2403^{*}$ & -2.8628 & $-3.2616^{*}$ & $-3.5595^{*}$ & $-3.4411^{*}$ \\
\hline & $(2.4551)$ & $(2.2539)$ & $(2.3606)$ & $(2.4138)$ & $(2.5451)$ & $(2.5430)$ & $(2.6015)$ \\
\hline \multirow[t]{2}{*}{ Log (population) } & 0.1652 & 0.1493 & 0.1184 & $0.2022^{*}$ & 0.1193 & 0.1659 & $0.1945^{*}$ \\
\hline & $(0.1451)$ & $(0.1372)$ & $(0.1282)$ & $(0.1407)$ & $(0.1327)$ & $(0.1346)$ & $(0.1244)$ \\
\hline \multirow{2}{*}{ ICRG, t-1 } & -0.0126 & $-0.0354^{* *}$ & $-0.0272^{*}$ & $-0.0406^{* * *}$ & $-0.0407^{* * *}$ & $-0.0345^{\star *}$ & $-0.0418^{* * *}$ \\
\hline & $(0.0218)$ & $(0.0155)$ & $(0.0169)$ & $(0.0167)$ & $(0.0168)$ & $(0.0166)$ & $(0.0176)$ \\
\hline Women in & -0.0447 & & & & & & \\
\hline parliament, t-1 & $(0.0442)$ & & & & & & \\
\hline Years of & & -0.0088 & & & & & \\
\hline suffrage & & $(0.0153)$ & & & & & \\
\hline Female labor & & & $-0.0318^{*}$ & & & & \\
\hline force, $t-1$ & & & $(0.0244)$ & & & & \\
\hline Female life & & & & $-0.0597^{* * *}$ & & & \\
\hline expectancy, t-1 & & & & $(0.0222)$ & & & \\
\hline Female/male life & & & & & $-13.4462^{*}$ & & \\
\hline expectancy, t-1 & & & & & $(9.8180)$ & & \\
\hline Female second. & & & & & & -0.0158 & \\
\hline school enroll., t-1 & & & & & & $(0.0148)$ & \\
\hline Female/male sec. & & & & & & & $-2.5503^{* * *}$ \\
\hline school enroll., t-1 & & & & & & & $(0.9040)$ \\
\hline \multirow[t]{2}{*}{ Constant } & -2.2718 & -2.1711 & 0.2310 & $-4.2433^{*}$ & 10.8101 & $-4.8353^{* *}$ & $-4.0278^{*}$ \\
\hline & $(3.6370)$ & $(3.2886)$ & $(3.0227)$ & $(3.1843)$ & $(9.4680)$ & $(2.9228)$ & $(3.1202)$ \\
\hline $\mathrm{N}$ & 863 & 1259 & 1269 & 1269 & 1269 & 1230 & 1230 \\
\hline Pseudo R2 & .08 & .09 & .09 & .10 & .10 & .09 & .11 \\
\hline
\end{tabular}

Robust standard errors in parentheses, ${ }^{* * *} \mathrm{p}<0.01,{ }^{* *} \mathrm{p}<0.05,{ }^{*} \mathrm{p}<0.1$ (one-tailed test) 
Whereas economic development and democracy can help to improve the situation of women and reduce the gender gap (Brown 2004; Dollar \& Gatti 1999), additional efforts are required to overcome cultural obstacles and economic inefficiencies. For this reason, and to speed up the process, states need to actively pursue policies that provide public goods such as sufficient education not just to girls but also to adult women. Through investment in education a government can signal to the population that it cares and tries to improve the general welfare (Thyne 2006). The results of the present study suggest, however, that governments should especially target female school enrollment which also lays the ground for better job opportunities for women, another factor that contributes to growth and peace. Rather than increasing the military budget as implied by the literature that links civil peace to a militarily strong state, governments with scarce resources should choose to invest in measures that reduce gender disparities. Investment in the education and health of women is not just a road to more development but can also help in promoting domestic stability and peace.

\section{References}

Azam, J.-P. 2001, "The Redistributive State and Conflicts in Africa." Journal of Peace Research 38(4): 429-444.

Barro, R. J. 1997, Determinants of Economic Growth, Cambridge, MA: The MIT Press.

Brown, D. S. 2004, "Democracy and Gender Inequality in Education: A Cross-National Examination." British Journal of Political Science 34 (1): 137-192.

Caprioli, M. 2003, "Gender equality and state aggression: The impact of domestic gender equality on state first use of force." International Interactions 29: 195-214.

Caprioli, M. 2005, "Primed for Violence: The Role of Gender Inequality in Predicting Internal Conflict." International Studies Quarterly 49: 161-178.

Collier, P. \& A. Hoeffler 2004, "Greed and Grievance in Civil War." Oxford Economic Papers 56 (4): 563-95.

Dollar, D., Fisman, R., \& Gatti, R. 2001, "Are Women Really the "Fairer" Sex? Corruption and Women in Government." Journal of Economic Behavior \& Organization 46: 423-429.

Dollar, D. \& R. Gatti 1999, "Gender inequality, income, and growth: Are good times good for women?" Policy Research Report on Gender and Development Working Paper Series, Working Paper No. 1, Washington, DC: World Bank.

Fearon, J. D., \& D. D. Laitin 2003, "Ethnicity, Insurgency, and Civil War.” American Political Science Review 97 (1): 1-16.

Gleditsch, N. P., P. Wallensteen, M. Eriksson, M. Sollenberg, \& H. Strand. 2002, "Armed Conflict 1946-2001: A New Dataset." Journal of Peace Research 39: 615-37.

Hegre, H., T. Ellingsen, S. Gates, and N. P. Gleditsch 2001, “Towards a Democratic Civil Peace? Democracy, Political Change, and Civil War 1816-1992." American Political Science Review 95:17-33.

Hegre, H, \& N. Sambanis 2006, "Sensitivity Analysis of Empirical Results on Civil War Onset." Journal of Conflict Resolution 50: 508-35.

Heston, A., Summers, R., \& Aten, B. 2002, Penn World Table, Version 6.1. Center for International Comparisons at the University of Pennsylvania.

Holmenberg, S., B. Rothstein \& N. Nasiritousi 2009, "Quality of Government: What you get" Annual Review of Political Science 12: 135-161.

Keefer, P. and Knack, S. 1995, "Institutions and economic performance: Cross-country tests using alternative institutional measures." Economics and Politics 7: 207-227.

Marshall, M. G., \& K. Jaggers 2000, Polity IV Project: Dataset Users Manual. http://www.bsos.umd.edu/cidcm/inscr/polity/ index.htm.

Melander, E. 2005a, "Gender Equality and Intrastate Armed Conflict.” International Studies Quarterly 49: 695-714.

Melander, E. 2005b, "Political Gender Equality and State Human Rights Abuse.” Journal of Peace Research 42(2): 149-166.

Nincic, M. \& D. J. Nincic 2002, "Race, Gender, and War." Journal of Peace Research 39(5): 547-568.

Plümper, T. \& E. Neumayer 2006, "The Unequal Burden of War: The Effect of Armed Conflict on the Gender Gap in Life Expectancy." International Organization 60: 723-754.

Regan, P. M. \& A. Paskeviciute 2003, "Women's Access to Politics and Peaceful States." Journal of Peace Research 40(3): 287302.

Swamy, A., Knack, S., Lee, Y., \& Azfar, O. 2001, "Gender and corruption." Journal of Development Economics 64: 25-55.

Thomas, S. 1991, "The impact of women on state legislative policies." The Journal of Politics 53(4): 958-976.

Thyne, C. L. 2006, ABC's, 123's, and the Golden Rule: The Pacifying Effect of Education on Civil War, 1980-1999. International Studies Quarterly 50(4): 733-754.

Tzannatos, Z. 1999, "Women and labor market changes in the global economy: growth helps, inequalities hurt and public policy matters." World Development 27(3), 551-569.

Weede, E. 1998, "Why People Stay Poor Elsewhere”, in: Seligson, M. A. and Passe-Smith, J. T. (eds.). Development and Underdevelopment, 2 nd ed. Boulder.

Wilcox, C., L. Hewitt \& D. Allsop 1996, „The Gender Gap in Attitudes Toward the Gulf War: A Cross-National Perspective." Journal of Peace Research 33(1): 67-82.

Wood, E. J. 2006, "Variation in Sexual Violence during War." Politics \& Society 34(3): 307-341.

World Bank 2004, World Development Indicators 2004 CDROM. Washington, DC: World Bank. 